\title{
Shielding Gas Influence On AA5086 Welded Joints: Residual Stresses Analysis, Microstructural Characterisation and Mechanical Properties
}

\author{
Maria Cindra Fonseca \\ Universidade Federal Fluminense - Rua Passo da Patria \\ Marcos Caetano Melado \\ Universidade Federal Fluminense - Rua Passo da Patria \\ Marcel Souza ( $\square$ marcelfreitas@id.uff.br) \\ Universidade Federal Fluminense https://orcid.org/0000-0002-2489-7399

\section{Cássio Barbosa} \\ Instituto Nacional de Tecnologia
}

\section{Research Article}

Keywords: aluminium alloy AA5086, GTAW process, residual stresses, mechanical properties, microstructural characterisation

Posted Date: October 22nd, 2021

DOl: https://doi.org/10.21203/rs.3.rs-965224/v1

License: (9) This work is licensed under a Creative Commons Attribution 4.0 International License. Read Full License

Version of Record: A version of this preprint was published at The International Journal of Advanced Manufacturing Technology on February 12th, 2022. See the published version at https://doi.org/10.1007/s00170-022-08833-w. 


\section{Abstract}

Samples of AA5086 aluminium alloy were welded by gas tungsten arc welding (GTAW) with alternating current using three different shielding gases. The samples were welded with pure argon ( $\mathrm{Ar}$ ), a mixture of argon and helium $(\mathrm{Ar}+\mathrm{He})$ and a new mixture composed of argon, nitrous oxide and oxygen $\left(\mathrm{Ar}+\mathrm{N}_{2} \mathrm{O}+\right.$ $\mathrm{O}_{2}$ ). The effect of the shielding gas on the residual stresses and on the mechanical and microstructural properties of the welded joints was evaluated and compared with the base metal. The new gas mixture produced compressive residual stresses in the longitudinal and transverse directions in the weld metal. Tensile test of welded joints indicated similar values for yield strength and ultimate tensile strength; however, these values were lower compared to the base metal. The new gas mixture provided a welded joint with hardness values in the weld metal and heat affected zone close to the base metal values and with greater magnitude compared to samples welded using pure argon and mixture of argon and helium. Microstructural characterisation performed by optical and scanning electron microscopy showed that the new mixture produced welded joints with lower porosity.

\section{Introduction}

Al-Mg alloys (AA 5XXX series) are an important group of non-heat treatable aluminium alloys that can only be hardened by solid solution and mechanical working. Magnesium is the main alloying element and additions of up to $6 \%$ lead to solute hardening combined with efficient strain hardening. These alloys have a good strength-to-weight ratio, excellent corrosion resistance and good weldability, resulting in a wide range of applications in the marine, chemical and automotive industries [1-5].

The gas tungsten arc welding (GTAW) process provides excellent quality and finishing of welded components and is particularly suitable for the welding of aluminium alloys [6-8]. In this process, the shielding gas has an important role as they affect the quality of the joints and consequently the mechanical and microstructural properties [9].

The shielding gases traditionally used in welding of aluminium alloys are inert gases, such as pure argon, pure helium or argon/helium blends. Recent researches evaluate shielding gases mixtures for GTAW process with the addition of small amounts of nitrogen, oxygen, and nitrous oxide to increase travel speed, change penetration and reduce surface tension, among other benefits. However, it is necessary to deepen the addition of these gases in traditional shielding gas, since they are more reactive and promote oxidation of the weld metal, especially for aluminium alloys [10].

Welding residual stresses arise due to differential thermal expansion and contraction of the weld metal and base metal. Although residual stresses are essential for the performance and service life of a welded component, there are no specific comparative analysis between different shielding gases used in aluminium alloys welded by GTAW process. Therefore, this work presents an innovative research on residual stresses using traditional shielding gas (pure $\mathrm{Ar}$ and $\mathrm{Ar}+\mathrm{He}$ ) and also a newly developed mixture of argon with low concentration of $\mathrm{O}_{2}$ and $\mathrm{N}_{2} \mathrm{O}$ [11]. 
The present work aims to study the residual stresses, measured by X-ray diffraction technique using $\sin ^{2} \psi$ method, and mechanical properties (mechanical strength and microhardness) of welded joints by the GTAW process of aluminium alloy AA5086, using different shielding gases.

\section{Materials And Experimental Methods}

The base metal (BM) used in this work was AA 5086- $\mathrm{H} 116$ aluminium alloy manufactured according to ASTM-B 928-04, tempering $\mathrm{H}-116$, in the form of sheet with $6.35 \mathrm{~mm}$ thick. The chemical composition and nominal mechanical properties of this material are shown in Tables 1 and 2, respectively.

Table 1

Chemical composition of AA5086 alloy (\% weight).

\begin{tabular}{|lllllllll|}
\hline $\mathrm{Si}$ & $\mathrm{Fe}$ & $\mathrm{Cu}$ & $\mathrm{Mn}$ & $\mathrm{Mg}$ & $\mathrm{Cr}$ & $\mathrm{Zn}$ & $\mathrm{Ti}$ & $\mathrm{Al}$ \\
\hline 0.40 & 0.50 & 0.10 & 0.45 & 4.00 & 0.15 & 0.25 & 0.15 & Balance \\
\hline
\end{tabular}

Table 2

Mechanical properties of AA5086 alloy.

\begin{tabular}{|lll|}
\hline $\begin{array}{l}\text { Tensile Yield Strength } \\
\text { (MPa) }\end{array}$ & Ultimate Tensile Strength (MPa) & $\begin{array}{l}\text { Hardness } \\
(\mathrm{HV})\end{array}$ \\
\hline 205 & 335 & 88 \\
\hline
\end{tabular}

The filler metal was TIG-HARRIS rod, aluminium alloy 5083, with a diameter of $3.2 \mathrm{~mm}$, and its chemical composition is shown in Table 3.

Table 3

Chemical composition of AA5083 filler metal (\% weight).

\begin{tabular}{|lllllllll|}
\hline $\mathrm{Si}$ & $\mathrm{Fe}$ & $\mathrm{Cu}$ & $\mathrm{Mn}$ & $\mathbf{M g}$ & $\mathrm{Cr}$ & $\mathrm{Zn}$ & $\mathrm{Ti}$ & $\mathrm{Al}$ \\
\hline 0.40 & 0.40 & 0.10 & 0.70 & 4.40 & 0.15 & 0.25 & 0.15 & Balance \\
\hline
\end{tabular}

Plates of size $250 \times 150 \mathrm{~mm}$, each with one of the edges chamfered by machining, were taken together to form a weld pad of $250 \times 300 \mathrm{~mm}$ with a single V-groove joint. Figure 1 presents the details of the joint.

The samples were welded by GTAW process (welding machine KEMPPI model Master TIG, 3500W, AC / DC) using different shielding gas, with alternating current in a flat position, according to the parameters shown in Table 4. For both samples, during the 1st pass (root pass), one locking bar and a back of copper were used to prevent warping of the plates. 
Table 4

Welding parameters.

\begin{tabular}{|llllll|}
\hline Sample & Shielding Gases & Flow & $\begin{array}{l}\text { Current } \\
(\mathrm{A})\end{array}$ & & \multicolumn{2}{l}{ Welding Speed (mm/min) } \\
\cline { 6 - 6 } & & & & $\begin{array}{l}\text { 1st Pass } \\
\text { (Root) }\end{array}$ & $\begin{array}{l}\text { 2nd Pass } \\
\text { (Filler) }\end{array}$ \\
\hline 1 & $\mathrm{Ar}$ (pure) & 10 & 202 & 150 & 80 \\
\hline 2 & $75 \% \mathrm{Ar}+25 \% \mathrm{He}$ & 10 & 202 & 150 & 100 \\
\hline 3 & $\begin{array}{l}\mathrm{Ar}+200 \mathrm{ppm} \text { of } \mathrm{N}_{2} \mathrm{O}+200 \mathrm{pm} \\
\text { of } \mathrm{O}_{2}\end{array}$ & 10 & 202 & 150 & 80 \\
\hline
\end{tabular}

Residual stresses of the welded samples were measured in the longitudinal $(\mathrm{L})$ and transverse $(\mathrm{T})$ directions to the bead in the weld metal (WM), heat-affected zone (HAZ) and base metal (BM) at the points shown in Figure 2a. The residual stresses were measured using the Xstress 3000 analyser, by X-ray diffraction technique using the $\sin ^{2} \psi$ method (uncertain of $\pm 15 \mathrm{MPa}$ ), Crka radiation $(\lambda \mathrm{Crka}=2.29092 \AA$ ) and diffracting the (222) plane of aluminium with angle $2 \theta=156.98^{\circ}$.

Micrographs of samples of each welding condition were performed. The samples were ground, polished and etched with a solution of $2 \mathrm{ml}$ of HF in $100 \mathrm{ml}$ of water. The etching time was $90 \mathrm{~s}$ for WM and HAZ and $60 \mathrm{~s}$ for the base metal. The samples were analysed by optical microscopy (OM) and scanning electron microscopy (SEM) with qualitative analysis of porosity in the welded joints.

The Vickers microhardness test was performed with a load of $25 \mathrm{~g}$ for $15 \mathrm{~s}$. The measurement of microhardness was carried out at the top, centre and root in the WM, HAZ (left and right of weld bead) and BM (left and right of weld bead). The result for each region is an average of the values obtained at the top, centre and root positions (Figure 2b).

The tensile test was performed in accordance with ASTM B557M (Figure 2c) using INSTRON 3382 Testing Machine with a speed of $2 \mathrm{~mm} / \mathrm{s}$ at room temperature. Four tensile test samples were made for each welding condition and base metal.

\section{Results And Discussion}

Residual stresses in longitudinal and transverse directions were analysed in the weld metal (WM), heataffected zone (HAZ) and base metal (BM) in each sample after welding. The results are shown in Figure 3.

The longitudinal residual stresses at the joints of each welding condition had a homogeneous and tensile behaviour in the HAZ and BM, while the WM showed compressive stresses with the new mixture $\left(\mathrm{Ar}+\mathrm{O}_{2}\right.$ $+\mathrm{N}_{2} \mathrm{O}$ ) and tensile ones with $\mathrm{Ar}+\mathrm{He}$ and pure Ar. The high longitudinal tensile residual stresses in the HAZ may have contributed to the reduction of the mechanical strength of the welded joint, because all specimens broke in this region. 
In the transverse direction, the behaviour of residual stresses in welded specimens with the $\mathrm{Ar}+\mathrm{He}$ and the new gas mixture ( $\mathrm{Ar}+\mathrm{O}_{2}+\mathrm{N}_{2} \mathrm{O}$ ) was very similar with high compressive values in the $\mathrm{BM}$, low tensile values in the HAZ and compressive in WM. As occurred in the longitudinal direction, the welded joint with the protection of pure Ar can be considered the most critical condition with tensile residual stresses around $50 \%$ of the yield strength initially reported by the manufacturer in Table 2 .

Therefore, the new mixture showed a beneficial residual stresses state in relation to the other welded joints. However, the tensile residual stresses in the HAZ made this region of the joint critical and with a tendency to fail.

Figure 4 shows the presence of pores in WM, especially in welded joints with pure Ar and $\mathrm{Ar}+\mathrm{He}$. Porosity is always present in aluminium samples welded by GTAW process with pure Ar, as reported by Prakash et al. [12], and the addition of He to the blend can significantly reduce this defect due to the higher thermal conductivity of $\mathrm{He}$, which results in greater energy transferred to the weld pool.

In Figure 4c, which corresponds to the welded joint using the new mixture, it can be observed more refined grains and that the formation of porosity was much lower compared to welded joint with previous shielding gases. Additionally, it was verified the presence of a crack, which may have arisen due to the alignment of the pores.

Pores form due to the sharp decrease in hydrogen solubility during the solidification process, since the solubility of hydrogen in the molten aluminium is about 20 times higher than in the solid aluminium. The formation of pores can be reduced by proper joint preparation, use of high purity shielding gas with lowdew-point and careful storage of the filler metal. However, the 5XXX series filler alloys, as used in this research, are particularly susceptible to surface oxide hydration, which promotes the porosity formation $[13,14]$.

In Figure 5, the joint welded with pure Ar had a more critical porosity profile, with deeper pores compared to joints welded using the other shielding gases, being this result consistent with Prakash et al. [12]. Additionally, Arana et al. [15] also observed that argon generated greater porosity area percentage compared to a three-phase mixture $\mathrm{Ar}+\mathrm{O}_{2}+\mathrm{N}_{2} \mathrm{O}$ mixture considering the same shielding gas flow rate and deposition strategy in the wire-arc additive manufacturing (WAAM) process with ER5356 filler metal. Figure $5 \mathrm{c}$ showed the presence of dispersoids, particles of the $\mathrm{Al}(\mathrm{Fe}) \mathrm{MnSi}$ phase, which inhibit grain growth in aluminium alloys by anchoring the movement of grain boundaries $[16,17]$.

The joint welded with $\mathrm{Ar}+\mathrm{He}$ (Figure 6) presented an intermediate porosity condition, confirming what was noticed in the micrographs by optical microscopy. The pore alignments showed in Figure 6a can make the joint susceptible to crack formation.

Viskoc et al. [18], evaluating the effect of shielding gases on the properties of AW 5083 aluminium alloy laser weld joints with 5087 filler metal, found that, compared to welding process with pure argon, there was a $50 \%$ reduction in porosity formation using $\mathrm{Ar}+5 \% \mathrm{He}$ and about 30\% using $\mathrm{Ar}+30 \% \mathrm{He}$. The extra 
heat potential of He can reduce gas entrapment and thus porosity by widening the weld fusion and penetration in $\mathrm{Ar}+\mathrm{He}$ blends.

The joint welded with the new mixture (Figure 7) showed lower porosity, also corroborating what was observed previously by optical microscopy. Although Miller et al. [10] did not perform a specific porosity analysis when using different shielding gases for aluminium alloy welding, the mixture with $\mathrm{Ar}+200 \mathrm{ppm}$ $\mathrm{N}_{2} \mathrm{O}+200$ ppm $\mathrm{O}_{2}$ showed an excellent bead appearance and generally better characteristics when compared with use of only one active gas at the same total concentration.

Figure 8 shows the average values of yield strength $\left(\sigma_{\mathrm{YS}}\right)$ and ultimate tensile strength $\left(\sigma_{\mathrm{UTS}}\right)$ obtained in the tensile tests carried out on the base metal and for each welding condition.

The welded joints presented, in general, yield strength and ultimate tensile strength equivalent. Vyskoc et al. [18] have shown that the shielding gas does not cause any change in the yield strength and ultimate tensile strength, which can also be seen in Figure 8. Therefore, it can be concluded from these results that shielding gas was not a significant factor on the tensile mechanical properties.

For all welding conditions, the ultimate tensile strength was about $12 \%$ lower compared to the base metal and the yield strength was reduced by $38 \%$ (for samples welded $\mathrm{Ar}$ and $\mathrm{Ar}+\mathrm{He}$ ) and $33 \%$ (for the sample welded with the new mixture). Srivatsava et al. [19] obtained a yield strength of $150 \mathrm{MPa}$ and a ultimate tensile strength of about $290 \mathrm{MPa}$ in samples of AA5083 welded by the non-pulsed GTAW process, being these values lower than those indicated for the base metal. This result is in agreement with Vasu et al. [20], who stated that the tensile properties of welded joints are significantly affected by the loss of alloying elements caused by evaporation.

The weld performed with the new mixture showed better yield strength when compared with other weld joints, especially when compared to the sample welded with Ar, where the difference was $10 \mathrm{MPa}$. This result was consistent with the microstructural analysis, where the new mixture presented less porous formation and, consequently, less stress concentration. Additionally, the tensile residual stresses in this joint had smaller magnitudes, compared to the other joints, in the longitudinal direction.

In both welding conditions, all specimens fractured in the HAZ, which is consistent with the microstructural analysis, since the grains are coarser in this region, reducing the resistance of the material. The influence of tensile residual stresses in this region may also have occurred.

Vickers microhardness results at weld metal (WM), heataffected zone left (HAZL) and right (HAZR) and base metal left (BML) and right (BMR) are presented in Figure 9.

The Vickers microhardness of the samples welded with $\mathrm{Ar}$ and $\mathrm{Ar}+\mathrm{He}$ were similar. The base metal presented a higher value in relation to the heat-affected zone and weld metal in both conditions.

Vasu et al. [20] also observed higher hardness values in the base metal compared to the weld metal in AA5059-H136 aluminium alloy welded joints by GTAW and GMAW processes. 
Vyskoc et al. [18] also found that the lowest Vickers microhardness values in the weld bead were obtained when welding with Ar and, thus, the use of He in the mixture caused an increase in this mechanical property. They reported that the Vickers microhardness in the centre of the weld bead was 59 $\mathrm{HV}$ for $\mathrm{Ar}$ and $60 \mathrm{HV}$ for $\mathrm{Ar}+30 \% \mathrm{He}$, and these values are close to those observed in Figure 9.

The new mixture $\left(\mathrm{Ar}+\mathrm{N}_{2} \mathrm{O}+\mathrm{O}_{2}\right.$ ) provided a joint with average microhardness values in $\mathrm{HAZ}$ and WM close to $\mathrm{BM}$ and with greater magnitude in relation to the other welded joints. These results of the new mixture are consistent with the microstructure analysis, which showed refined grains in the WM.

\section{Conclusions}

The present work, which aimed to study the residual stresses and mechanical properties of welded joints by the GTAW process of aluminium alloy AA5086, using different shielding gases, allowed the following conclusions:

1. The gas mixtures of argon with helium and the new mixture $\left(\mathrm{Ar}+200 \mathrm{ppm} \mathrm{N}_{2} \mathrm{O}+200 \mathrm{ppm} \mathrm{\textrm {O } _ { 2 }}\right)$ provided welded joints with better residual stress state in the weld metal compared to pure argon shielding gas.

2. Microstructural analysis showed the presence of porosity in the weld metal in all joints. However, the new mixture provided less porosity and more refined grains in the weld metal and heataffected zone, thus enabling better mechanical properties.

3. The welded joints showed similar yield strength and ultimate tensile strength, but these values were lower than those of the base metal. The joint welded with the new mixture presented a small improvement in mechanical properties compared to the other joints.

4. The new mixture provided a welded joint with hardness values in the weld metal and heataffected zone close to the base metal values and with greater magnitude compared to samples using traditional shielding gases (pure $\mathrm{Ar}$ and $\mathrm{Ar}+\mathrm{He}$ ).

\section{Declarations}

\section{Funding}

This study was financed in part by the Coordenação de Aperfeiçoamento de Pessoal de Nível Superior Brasil (CAPES) - Finance Code 001. The authors would also like to thank White Martins Company for the welded sample and the Brazilian research agencies CNPq (304129/2018-6) and FAPERJ for the financial support.

Conflict of interest The authors declare that they have no conflict of interest.

Availability of data and material Not applicable. 
Code availability Not applicable.

Ethics approval Not applicable.

Consent to participate Written informed consent for publication was obtained from all participants.

Consent for publication Written informed consent for publication was obtained from all participants.

Authors' contributions Maria Cindra Fonseca: Conceptualization, Formal analysis, Funding acquisition, Investigation, Methodology, Project administration, Resources, Supervision, Validation, Visualization, Writing - review \& editing.

Marcos Caetano Melado: Conceptualization, Formal analysis, Investigation, Methodology, Writing original draft.

Marcel Freitas de Souza: Investigation, Writing - original draft, Writing - review \& editing.

Cássio Barbosa: Investigation, Methodology, Resources, Supervision, Validation, Writing - original draft.

\section{References}

1. Wang BB, Xue P, Xiao BL, Wang WG (2020) Achieving equal fatigue strength to base material in a friction stir welded 5083-H19 aluminium alloy joint. Sci Technol Weld Joining 20:81-88. https://doi.org/10.1080/13621718.2019.1630571

2. Babu N, Natarajan U, Malayalamurthi R (2020) Evaluating mechanical and metallurgical properties of gas tungsten arc welded AA 5059 aluminium alloy joints. Mater Today Proc 22:353-363. https://doi.org/10.1016/j.matpr.2019.06.696

3. Engler O, Kuhnke K, Hasenclever J (2017) Development of intermetallic particles during solidification and homogenization of two AA 5xxx series Al-Mg alloys with different Mg contents. J Alloys Compd 728:669-681. https://doi.org/10.1016/j.jallcom.2017.09.060

4. Foley DL, Leff AC, Lang AC, Taheri ML (2020) Evolution of $\beta$-phase precipitates in an aluminummagnesium alloy at the nanoscale. Acta Mater 185:279-286.

https://doi.org/10.1016/j.actamat.2019.10.024

5. Fillizzola DM, Santos TS, Miranda AG et al (2021) Annealing Effect on the Microstructure and Mechanical Properties of AA 5182 Aluminum Alloy. Mater Res 24(4):e20200545. https://doi.org/10.1590/1980-5373-MR-2020-0545

6. Venkat Ramana G, Yelamasetti B, Vishnu Vardhan T (2021) Study on weldability and effect of post heat treatment on mechanical and metallurgical properties of dissimilar AA 2025, AA 5083 and AA7075 GTAW weld joints. Mater Today Proc 46:878-882. https://doi.org/10.1016/j.matpr.2020.12.1115 
7. Sathishkumar D, Das AD (2021) Investigations on effect of process parameters on GTAW of aluminium alloy welding using full factorial design technique. Mater Today Proc 37:621-626. https://doi.org/10.1016/j.matpr.2020.05.624

8. Zhang Z, Zhang L, Wen G (2019) Study of inner porosity detection for Al-Mg alloy in arc welding through online optical spectroscopy: Correlation and feature reduction. J Manuf Processes 39:7992. https://doi.org/10.1016/j.jmapro.2019.02.016

9. Peasura P, Watanapa A (2012) Influence of Shielding Gas on Aluminum Alloy 5083 in Gas Tungsten Arc Welding. Procedia Eng 29:2465-2469. https://doi.org/10.1016/j.proeng.2012.01.333

10. Miller PL, Lyttle KA, Neff JB et al inventor (2021) Praxair Technology, assignee. Welding gas compositions and method for use. United States patent US 11,040,417 B2. 2021 Jun 22

11. Wan Q, Zhao Y, Zhao T, Yan D, Wang G, Wu A (2021) Influence of restraint conditions on residual stress and distortion of 2219-T8 aluminum alloy TIG welded joints based on contour method. J Manuf Processes 68:796-806. https://doi.org/10.1016/j.jmapro.2021.05.065

12. Prakash J, Tewari SP, Srivastava BK (2011) Shielding Gas for Welding of Aluminium Alloys by TIG/MIG Welding-A Review. Int J Mod Eng Res 1:690-699

13. Hakem M, Lebaili S, Miroud J, Bentaleb A, Toukali S (2012) Welding and characterization of 5083 aluminium alloy. Metal 23:1-6

14. Poolperm P, Nakkiew W, Naksuk N (2020) Finite element analysis of the effect of porosity on residual stress in 2024 aluminium alloy GTAW. Mater Res Express 7:056518. https://doi.org/10.1088/20531591/ab906a

15. Arana M, Ukar E, Rodriguez I, Iturrioz A, Alvarez P (2021) Strategies to Reduce Porosity in AlMgWAAM Parts and Their Impact on Mechanical Properties. Metals 11:524. https://doi.org/10.3390/met11030524

16. Saimoto S, Singh MA, Langille MR, Kula A, Niewczas (2018) Identification of the role of Al-Fe-Mn-Si large casting dispersoids in age-hardenable aluminum alloys using small angle X-ray scattering. Mat Sci Eng A 734:51-58. https://doi.org/10.1016/j.msea.2018.07.085

17. Pan S, Quian F, Li C, Wang Z, Li Y (2021) Synergistic strengthening by nano-sized a-Al(Mn,Fe)Si and Al3Zr dispersoids in a heat-resistant Al-Mn-Fe-Si-Zr alloy. Mat Sci Eng A 819:141460. https://doi.org/10.1016/j.msea.2021.141460

18. Vyskoc M, Sahul M, Sahul M (2018) Effect of Shielding Gas on the Properties of AW 5083 Aluminum Alloy Laser Weld Joints. J Mater Eng Perform 27:2993-3006. https://doi.org/10.1007/s11665-0183383-x

19. Srivatsava M, Vang G, Kumar GNS (2016) Experimental study of mechanical properties of 5083 aluminium alloy using gas tungsten arc welding. Int $J$ Innov Res Sci Eng Technol 6:7324:7331. https://doi.org/10.15680/IJIRSET.2016.0505098

20. Vasu K, Chelladurai H, Ramaswamy A, Malarvizhi S, Balasubramanian V (2019) Effect of fusion welding processes on tensile properties of armor grade, high thickness, non-heat treatable aluminium alloy joints. Def Technol 15(3):353:362. https://doi.org/10.1016/j.dt.2018.11.004 
Figures

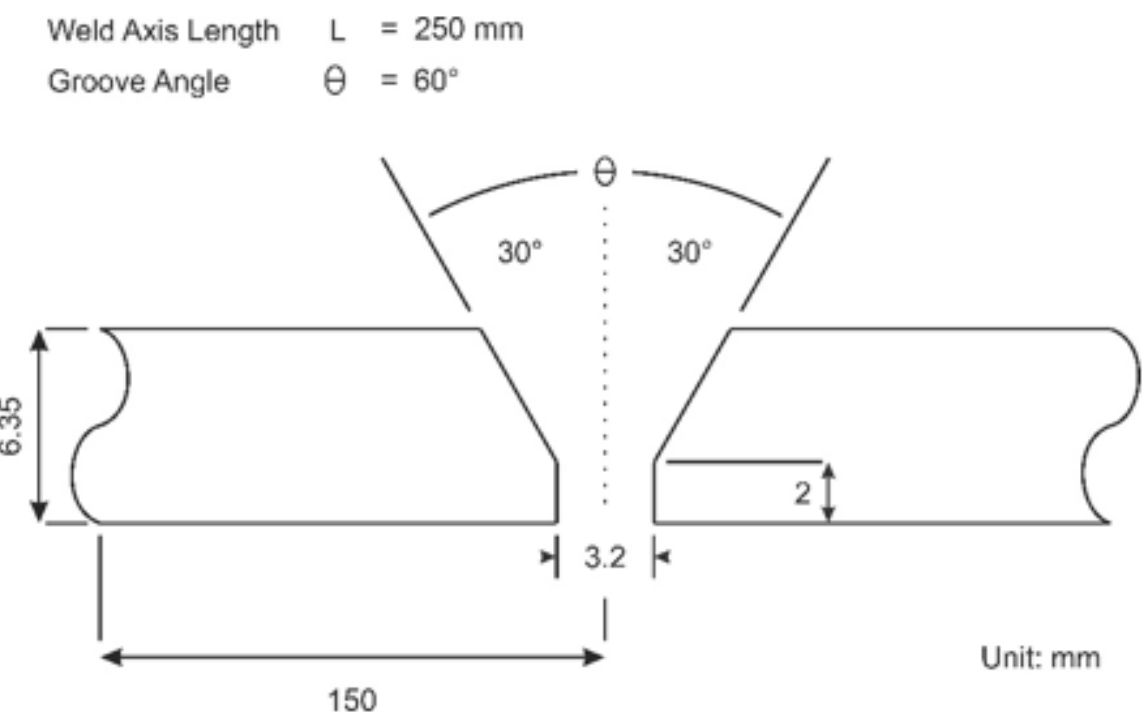

Figure 1

Welded joint details of single V-groove butt weld.
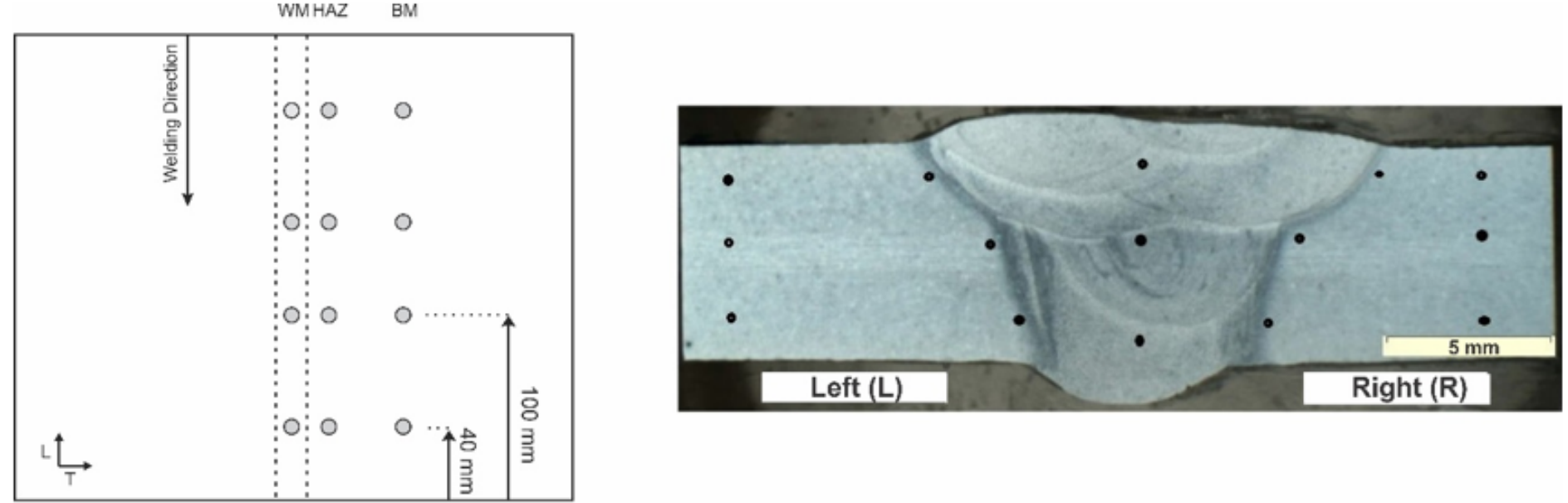

(a)

(b)

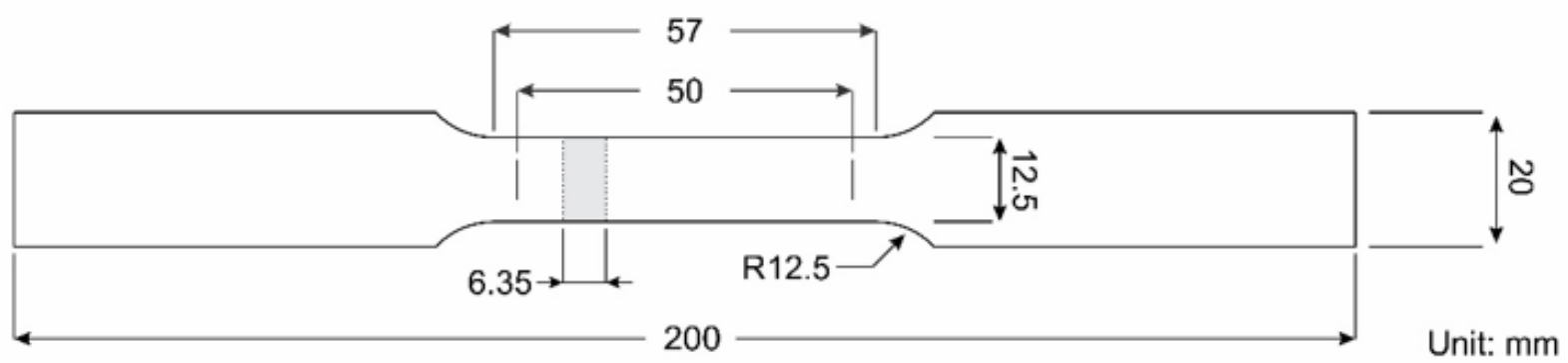

(c)

Figure 2 
(a) Measurement points of residual stresses; (b) Measurement points of hardness in the welded joint; (c) Dimensions of tensile test specimen (ASTM B557M).

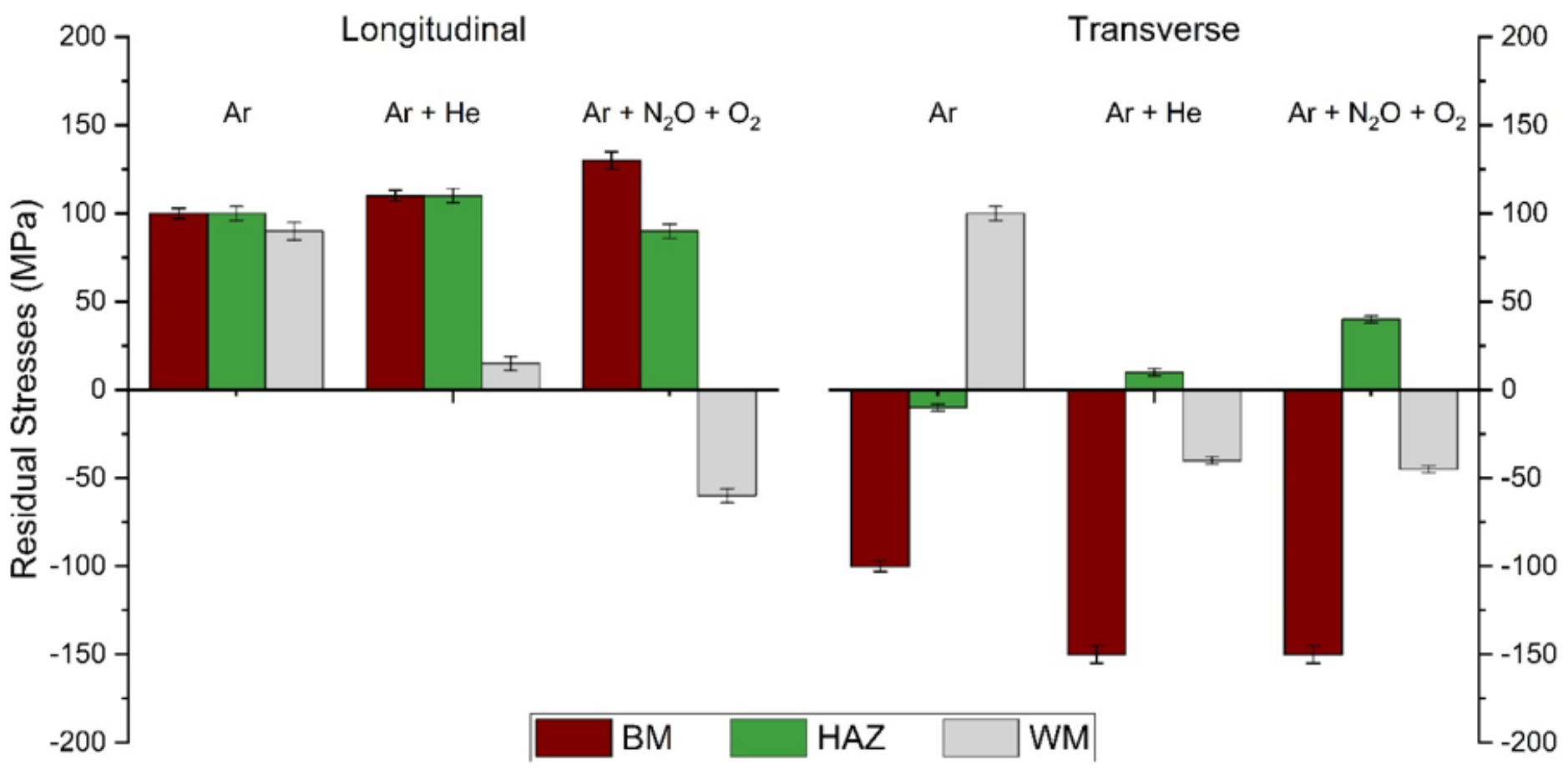

Figure 3

Residual stresses after welding using different shielding gases.

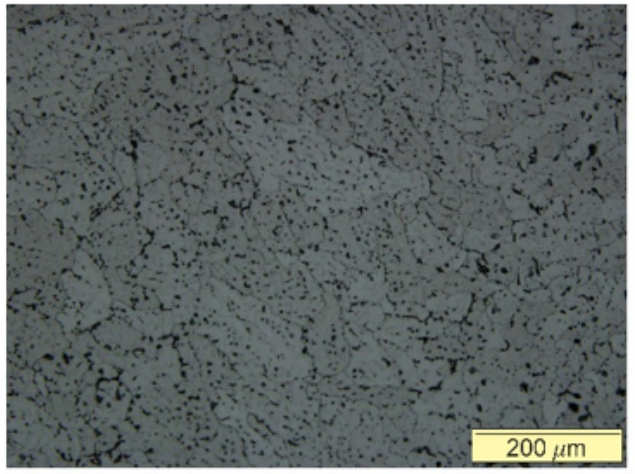

(a)

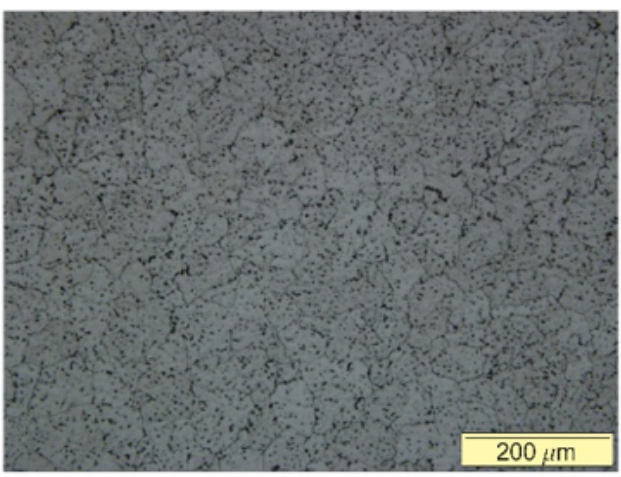

(b)

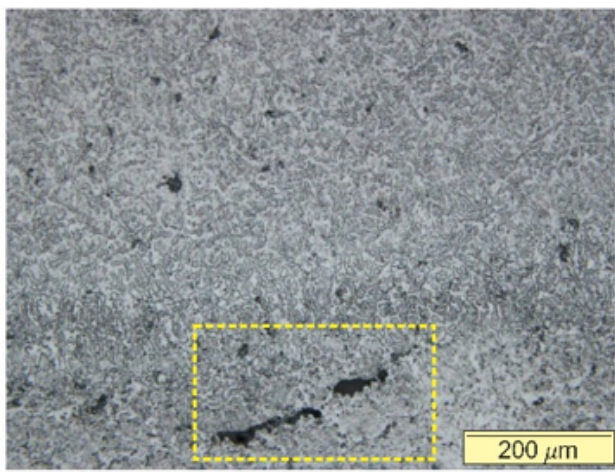

(c)

Figure 4

Optical microscopy of weld metal using different shielding gases: (a) pure $\mathrm{Ar}$; (b) $\mathrm{Ar}+\mathrm{He}$; (c) $\mathrm{Ar}+\mathrm{N} 2 \mathrm{O}+$ 02 (crack indicated in the yellow rectangle). 


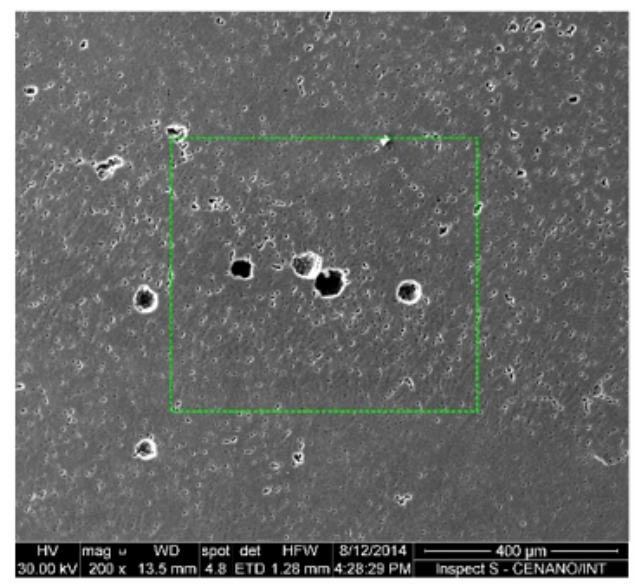

(a)

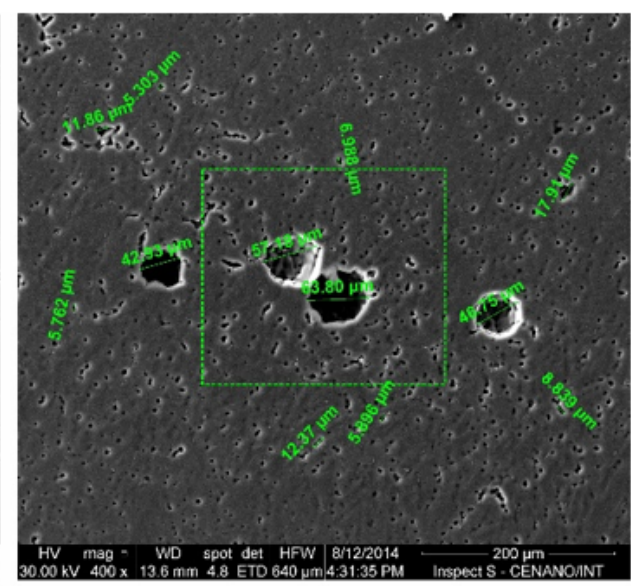

(b)

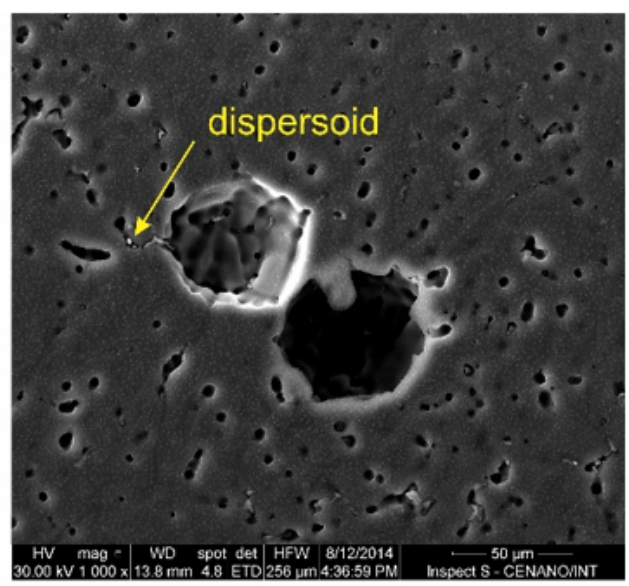

(c)

\section{Figure 5}

SEM of the welded joint with pure argon protection: (a) high porous concentration, (b) magnification of the area indicated in (a), (c) magnification of the area indicated in (b).

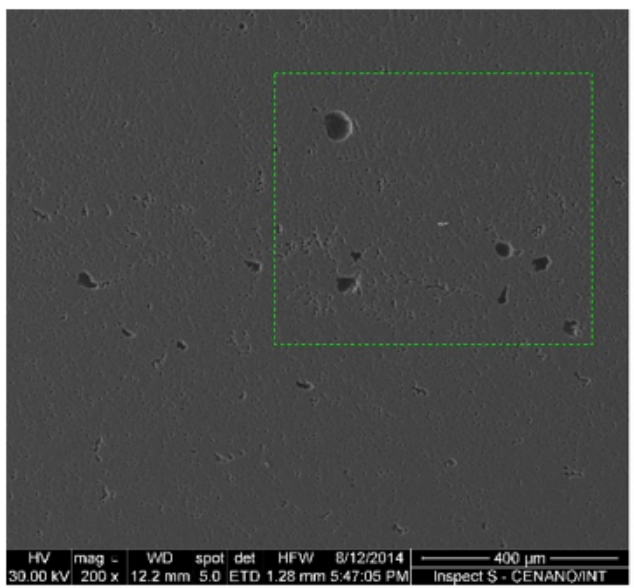

(a)

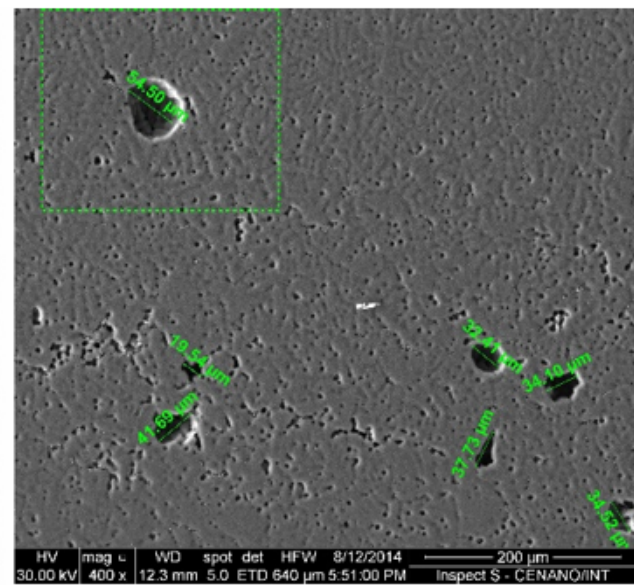

(b)

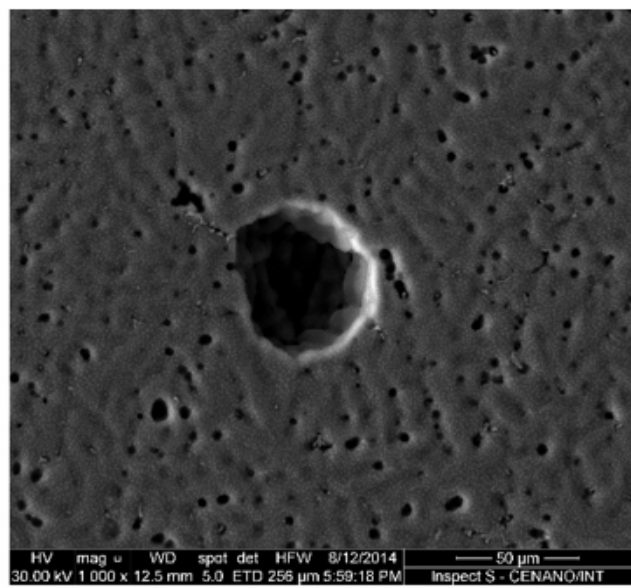

(c)

\section{Figure 6}

SEM of the welded joint with a mixture of $\mathrm{Ar}+\mathrm{He}$ : (a) intermediate porous concentration, (b) magnification of the area indicated in (a), (c) magnification of the area indicated in (b). 


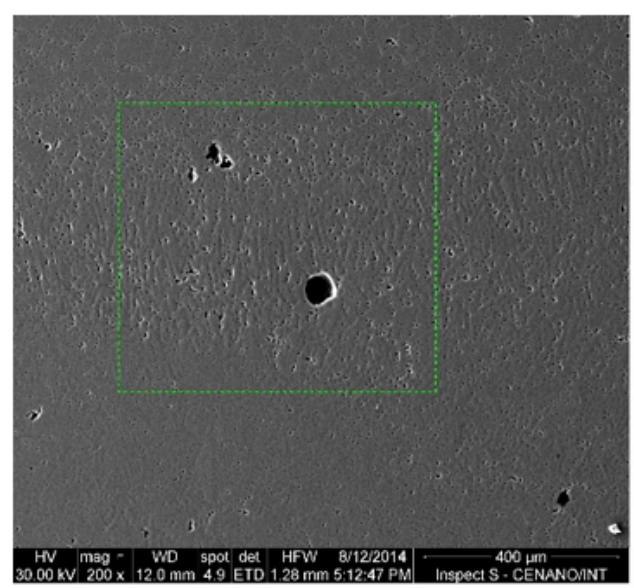

(a)

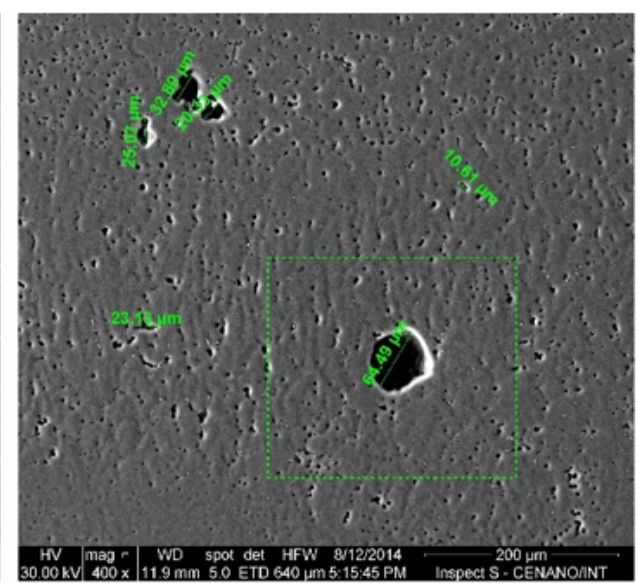

(b)

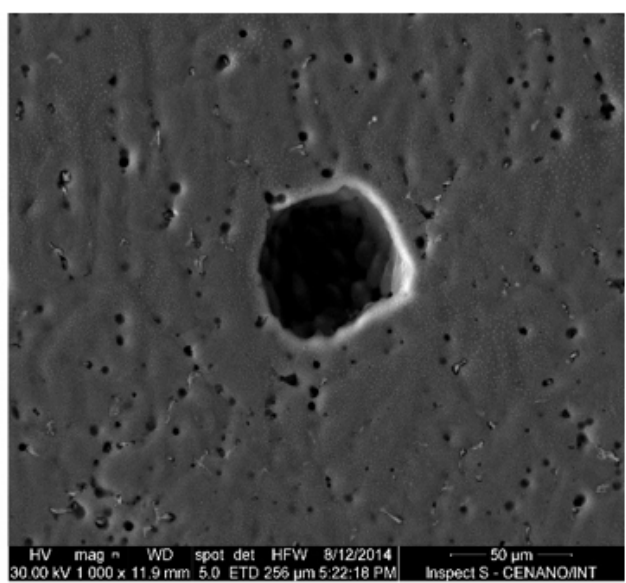

(c)

\section{Figure 7}

SEM of the welded joint with the new mixture $(\mathrm{Ar}+\mathrm{O2}+\mathrm{N} 2 \mathrm{O})$ : (a) low porous concentration, (b) amplification of the area indicated in (a), (c) amplification of the area indicated in (b).

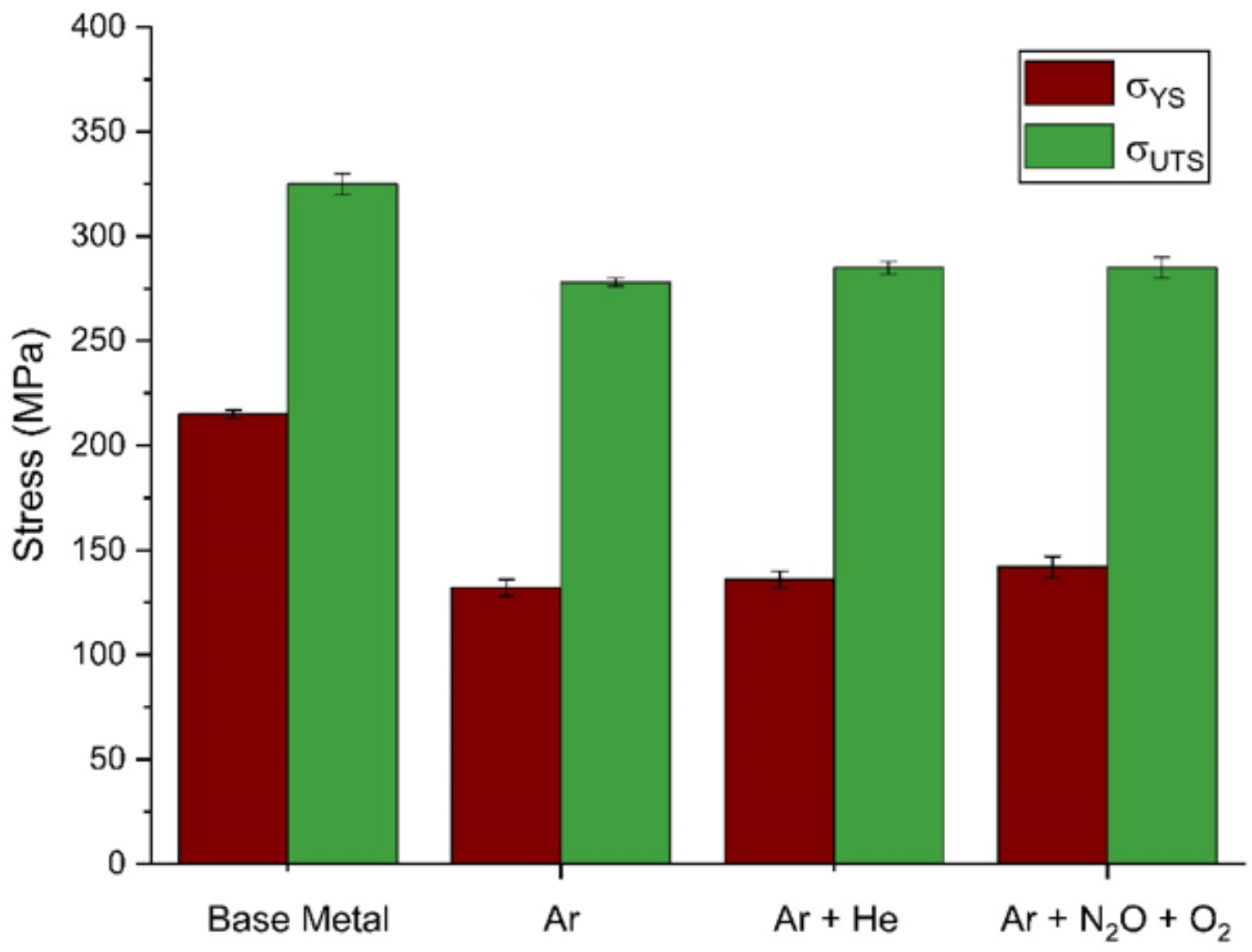

\section{Figure 8}

Mechanical properties of welded joints. 


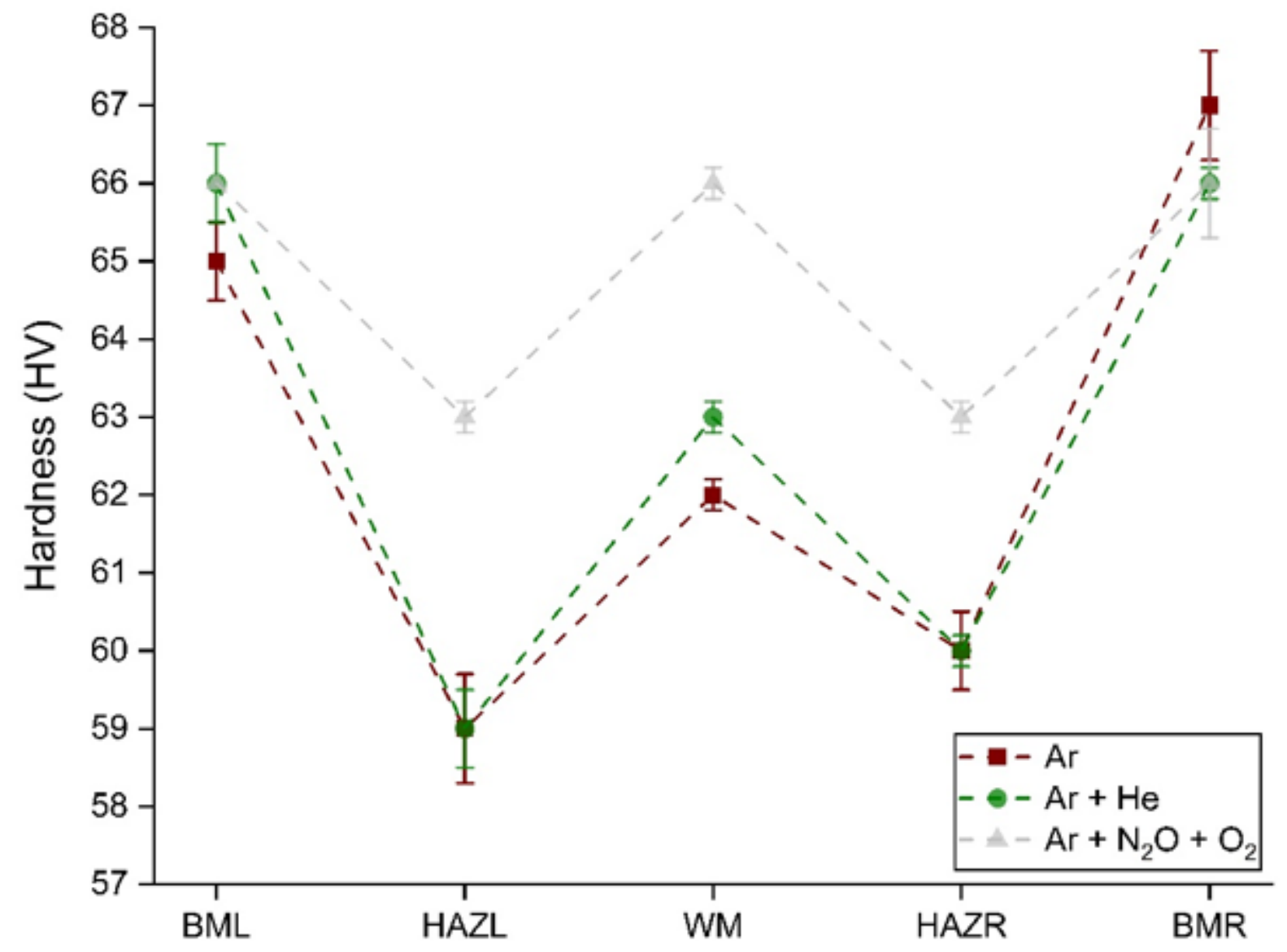

Figure 9

Microhardness Vickers in welded joints. 